\title{
Pesticide residue analysis in Clarias gariepinus sold in Wukari market Taraba State, Nigeria
}

\author{
Ogah E. ${ }^{\star}$, Longbap B. D., Ushie O. A., Malu S. P., Yerima E. A. and Gambo S. B. \\ Department of Chemical Sciences, Federal University Wukari, Nigeria. \\ *Corresponding author. Email: uhinyohe@gmail.com
}

Copyright (@) 2018 Ogah et al. This article remains permanently open access under the terms of the Creative Commons Attribution License 4.0, which permits unrestricted use, distribution, and reproduction in any medium, provided the original work is properly cited.

Received 6th November, 2017; Accepted 6th December, 2017

\begin{abstract}
This study reports the concentrations of the pesticide residues in Clarias gariepinus samples sold within Wukari Market using gas chromatography equipped with electron capture and flame photometric detectors. Among the pesticides analyzed in this study: $\alpha$-BHC, $\beta$-BHC, chlorothalonil, heptachlor, aldrin, o,p-DDE, endosulfan I and II, P,P-DDE, PCB 153, PF-38, P,P-DDT were below LOD while lindane $(0.006 \pm 0.0015)$ dieldrin $(0.007 \pm 0.0012 \mu \mathrm{g} / \mathrm{g})$, a-cypermethrin $(0.072 \pm 0.0036 \mu \mathrm{g} / \mathrm{g})$, b-cypermethrin $(0.039 \pm 0.0012 \mu \mathrm{g} / \mathrm{g})$, z-cypermethrin $(0.031 \pm 0.0014 \mu \mathrm{g} / \mathrm{g})$ were detected but at concentrations below the maximum regulatory limit (MRL) set by World Health Organization (WHO). However, adequate measures should be taken to preserve the aquatic life in the study area.
\end{abstract}

Key words: Clarias garepienus, organochlorine, organophosphate, pesticides, Wukari.

\section{INTRODUCTION}

Various activities such as farming, fishing, forestry, construction, mining, urban development and land pollution occurring in or near the watershed of a reservoir could bring about water quality problems and disruption in fish quality (Moshood, 2009). Nigeria is a densely populated country with a vast land size on which farmers cultivate a wide range of crops for public consumption and as a source of income. Intensive agricultural activities are a major threat to Nigerian fishery, wildlife and marine resources. In order to increase their yield, most farmers use agrochemicals, which can enter surface and ground waters through run-off from treated soils, leaching processes, aerial drift and inappropriate disposal methods thus changing water chemistry (Joseph et al., 2013). On entry into water bodies (lakes and rivers), pesticides cause immediate toxic effects on aquatic life (Darko and Akorto 2008).

Organochlorine pesticides continue to be reported as major pollutants with numerous investigations reporting the ubiquitous presence of Organochlorine pesticides globally (Hung et al., 2002). Chlorinated organic pesticides are very stable in both fresh and salt water and are resistant to photo degradation (Shokrzadeh et al., 2009). Organochlorine pesticides are very stable compounds for instance the degradation of dichlorodiphenyltrichloroethane (DDT) in soil ranges from 4 to 30 years (Afful et al., 2010). Organochlorine pesticides have also been implicated as cause of human breast and liver cancers, testicular tumours and lower sperm counts (Davies and Barlow, 1995). They are liposoluble compounds and capable of bioaccumulating in the fatty part of organs such as breast milk and fatty tissues (William et al., 2008). Since the pesticides are lipophilic in nature, their continued accumulation at low concentrations in the fat tissues of mammal might pose potential hazards in the long run (Metcaff, 1997).

In particular, organochlorine pesticides (OCPs) and polychlorinated biphenyls (PCBs) are two principal environmental pollutants due to their toxicity, mobility and persistence. Humans take up persistent organic pollutants (POPs) through skin absorption, respiration and ingestion of contaminated food. Skin absorption and respiration are not the main routes. Some researchers have confirmed that more than $90 \%$ of contaminants come from food (Furst et al., 1990). Among all foods, fish is one of the main sources of chemical contaminants although fish products account only for about $10 \%$ of diet or less (Alcock et al., 1998). 
Unlike the organophosphates (OPPs), Dichlorvos, Diazinon, Chlorpyrifos and Fenitrothion - which are readily deactivated and degraded by micro-organisms and therefore do not readily accumulate, the OCs residues are detectable in most surface water bodies and are bioconcentrated in shellfish and other biota in these ecosystems.

The detection of extracted OPPs can be carried out by using different GC detectors - photometric detector (FPD) (Berijani, 2006), nitrogen-phosphorus detector (NPD) (Giampiero et al., 2005), and electron capture detector (ECD) (Gonçalves and Alpendurada, 2002).

Thus, the general aim of this research is to determine the concentration of pesticide residue in muscle of Clarias garepienus fishes sold within Wukari metropolis of Taraba State.

\section{MATERIALS AND METHODS}

\section{Study area}

Wukari Town (the study area) is located on a geographic grid reference longitude $7^{\circ} 51^{\prime} \mathrm{N}$ and latitude $9^{\circ} 47^{\prime} \mathrm{E}$. The Donga river flows through the area and the Benue River forms a boundary with Nassarawa State to the Northwest. The town is the base of the Wukari Federation, a traditional State. It has an area of $4308 \mathrm{~km}^{2}$ and a population of 241,546 by the 2006 National Census. It has a temperature range of between 29 to $38^{\circ} \mathrm{C}$ and a rainfall of between 1500 to $2000 \mathrm{~cm}^{3}$ that last between the months of April and early October. Humidity is relatively low throughout the year, with average relative humidity values varying between 40 to $70 \%$.

\section{Materials}

Organic solvents especially dichloromethane which is toxic, were handled with care observing safety precautions, using efficient fume hoods and protective gloves. Silica gel (60-100 mesh ASTM) was purchased from Merck, Germany. Standard stock solutions of $\alpha, \beta, \delta$ BHC $(99.9 \% \mathrm{w} / \mathrm{w})$, lindane $(99.3 \% \mathrm{w} / \mathrm{w})$, DDT, DDD $(99.7 \% \mathrm{w} / \mathrm{w})$, aldrin $(99.9 \% \mathrm{w} / \mathrm{w})$, dichlorvos $(99.2 \% \mathrm{w} / \mathrm{w})$, endosulfan I and endosulfan II $(73.2 \% \mathrm{w} / \mathrm{w})$, dieldrin $(94.2 \% \mathrm{w} / \mathrm{w})$, diazinon $(94.2 \% \mathrm{w} / \mathrm{w})$, mevinfos $(94.2 \%$ w/w) purchased from Restek Corporation U.S.A., chlorpyrifos $(99.0 \% \mathrm{w} / \mathrm{w})$ was purchased from Chem Service (West Chester, PA, USA) and were prepared in acetonitrile at a concentration of $1000 \mathrm{mg} \mathrm{L}^{-1}$ and stored at $4^{\circ} \mathrm{C}$. From the dilution of stock, solutions were prepared containing the two pesticides (organochlorine and organophosphate) at concentrations of 10 and $20 \mathrm{mg} \mathrm{L}-1$ in the same solvent. Anhydrous sodium sulphate with a purity superior to $99 \%$ was also purchased from Vetec.

\section{Sampling}

Clarias gariepinus was selected for analysis in this study owing to its wide consumption. The study was conducted between April and September, 2017. Smoked species of the fish were bought from the Wukari market to asses the pesticide residue in them. The fish samples were crushed and pulverized to very fine particles. The samples were then sieved using mesh $400 \mu \mathrm{m}$ sieve size. Each of the crushed samples were transferred separately into a thermo insulator box and transported to the laboratory where they were stored in a freezer pending time for analysis.

\section{Liquid-liquid extraction}

Three fish samples weighing between 45 to $50 \mathrm{~g}$ were selected. $5 \mathrm{~g}$ of three replicate samples of the crushed fish were placed in extraction flasks separately. $25 \mathrm{~mL}$ of water was poured into each of the samples followed by $25 \mathrm{~mL}$ each of dichloromethane and ethyl acetate. The mixtures were allowed to settle for $15 \mathrm{~min}$ in a separating funnel before the aqueous layer was carefully poured into a 200 $\mathrm{mL}$ round bottom flask. $5 \mathrm{~g}$ of anhydrous sodium sulfate was added to each of the two solutions which were then transferred to the rotary evaporator. The extracts were collected using a $2 \mathrm{~mL}$ Vial for each of the samples and ready for silica gel clean up.

\section{Silica Gel clean up}

The clean-up column was packed with $2 \mathrm{~g}$ of activated silica gel at $50^{\circ} \mathrm{C}$ for $10 \mathrm{~min}$ and $3 \mathrm{~g}$ anhydrous sodium sulphate. The packed column was clamped with a retort stand and conditioned using $10 \mathrm{~mL}$ of hexane (99\%). The extract was passed through the conditioned column with a receiving flask beneath the column. The sample (analyte) put in the column was eluted with $10 \mathrm{~mL}$ hexane $(99 \%)$ and eluted further with $20 \mathrm{~mL}$ 2:1 Hexane:Acetone to recover the pesticide residues. The sample was collected into a round bottomed flask and concentrated using a rotary evaporator fitted to a vacuum pump to almost dryness and $2 \mathrm{~mL}$ ethyl acetate (99\%) was added. The mixture was then transferred to an auto sampler vial ready for Gas chromatographic analysis.

\section{GC-FPD analysis}

An Agilent 7890 Gas Chromatograph (GC) with Agilent 7693 Auto sampler equipped with electron capture detector and flame photometric detector were used for quantification. OC and OP compounds were completely separated using a HPS MS fused silica capillary column $(30 \mathrm{~m} \times 0.25 \mu \mathrm{m} \times 0.32 \mathrm{~mm}$ id). $1.0 \mu \mathrm{L}$ of analyte was 
Table 1. Mean concentration of Organochlorine pesticide levels $(\mu \mathrm{g} / \mathrm{g})$ in Clarias gariepinus

\begin{tabular}{lc}
\hline Organochlorine & Clarias gariepinus \\
\hline$\alpha$-BHC & - \\
$\beta$-BHC & - \\
Lindane & $0.006 \pm 0.0015$ \\
Chlorothalonil & - \\
Heptachlor & - \\
Aldrin & - \\
Heptachlor epoxide & - \\
o,p'-DDE & - \\
Endusulfan I & - \\
p,p'-DDE & - \\
Dieldrin & $0.007 \pm 0.0012$ \\
Endosulfan II & - \\
PCB 153 & - \\
PF-38 & - \\
p,p'-DDT & - \\
a-Cypermethrin & $0.072 \pm 0.036$ \\
b-Cypermethrin & $0.039 \pm 0.0012$ \\
z-Cypermethrin & $0.031 \pm 0.0014$ \\
\hline
\end{tabular}

Table 2. Mean Concentration of Organophosphate Pesticide $(\mu \mathrm{g} / \mathrm{g})$ in Clarias gariepinus Fish Samples.

\begin{tabular}{lc}
\hline Organophosphate & Clarias gareipinus \\
\hline Dichlorvos & - \\
Mevinphos & - \\
Dimethoate & - \\
Carbofurane & - \\
Diazinone & - \\
Pirmicarb & - \\
Dichlofenthion & - \\
Methyl parathion & - \\
Pirimiphos methyl & - \\
Malathion & - \\
Chloropyrifos & - \\
Fenthion & - \\
Parathion & - \\
Isofenphos & - \\
Bromophos ethyl & - \\
Ethion & - \\
Carbofenothion & - \\
PF-38 & - \\
\hline
\end{tabular}

injected into the GC on splitless mode with a 0.75 min vent delay. The injector temperature was maintained at $240^{\circ} \mathrm{C}$ and the initial oven temperature was set at $60^{\circ} \mathrm{C}$ for $1 \mathrm{~min}$ and then increased at a rate of $10^{\circ} \mathrm{C} / \mathrm{min}$ until it reached $200^{\circ} \mathrm{C}$, where it remained for $2 \mathrm{~min}$. The temperature was then increased at a rate of $10^{\circ} \mathrm{C} / \mathrm{min}$ until it reached $280^{\circ} \mathrm{C}$, where it remained for 3 min using this temperature program (Ogah et al., 2016).

\section{RESULTS AND DISCUSSION}

The results for the analysis of organochlorine and organophosphorus in Clarias gariepinus are as shown in Table 1 and 2 respectively. From Table 1, it can be observed that apart from lindane, dieldrin, a-cypermethrin, b-cypermethrin and z-cypermethrin were detected all other organochlorine pesticides were below limit of detection (LOD).

In the Clarias gariepinus sample analyzed, Cypermethrin and its metabolites (a-cypermethrin, bcypermethrin and z-cypermethrin) were recorded at higher concentration values of $0.072 \pm 0.036,0.039 \pm 0.0012$ and $0.031 \pm 0.0014 \mu \mathrm{g} / \mathrm{g}$ respectively. Cypermethrin is a synthetic pyrethrin $\left(\mathrm{C}_{21} \mathrm{H}_{20} \mathrm{C}_{12} \mathrm{O}_{3}\right)$, (USEPA, 2007). It is highly toxic to both freshwater and estuarine aquatic organisms, invertebrate sediment organisms. This was followed by dieldrin at a value of $0.007 \pm 0.0012 \mu \mathrm{g} / \mathrm{g}$ while lindane had the least occurrence with a mean concentration of $0.006 \pm 0.0015 \mu \mathrm{g} / \mathrm{g}$. However, the concentrations of dieldrin and lindane were below the WHO MRL of $0.01 \mathrm{ppm}$ in fish samples. Idowu et al. (2013) however recorded concentration below LOD while Adeyemi et al. (2011) detected dieldrin concentration of $0.032 \mathrm{ppm}$ in water samples of Lagos Lagoon. Farshid, (2012) reported values $0.45-1.50 \mathrm{ppm}$ of lindane which are higher than concentrations detected in this study. The low concentrations of dieldrin and lindane in this study are not unconnected with the restricted use of these pesticides around the source of the fish. Cypermethrin and its metabolites concentrations were higher than WHO MRL in fish samples. This was due to the extensive use of cypermethrin pesticides that come under trade names as "Best action". The concentration of dieldrin recorded in this study $(0.007 \mu \mathrm{g} / \mathrm{g})$ is in agreement with the $0.08 \mu \mathrm{g} / \mathrm{g}$ concentration in Tilapia zilli sample reported by Ezemonye et al. (2015).

From the Table 2, it can be observed that all the organophosphate pesticides were below limit of detection (LOD). However, a mean dichlorvos concentration of 1.02 $\mu \mathrm{g} / \mathrm{g}$ in Tilapia zilli sample from Alau dam in Borno State was reported by Joseph et al. (2013). The <LOD mean concentration recorded in this study was below the 0.04 $\mu \mathrm{g} / \mathrm{g}$ MRL set by WHO and FAO in fish samples and as such the result deviates from that reported by Joseph et al. (2013) due to low distribution of dichlorvos in the studied area.

\section{Conclusion}

The study was the first to be carried out within Wukari metropolis and it revealed that the fish samples analyzed 
(Clarias gariepinus) were contaminated by organochlorine. The order and concentration of these pesticides varied in the fish species. Hence, it can be concluded that the sources from which these fish samples were harvested were contaminated with pesticide runoffs from nearby agricultural lands. Regular monitoring of the fish bearing water bodies in Wukari should be carried out. Unhealthy methods of harvesting and preserving fish should be discouraged forth with.

\section{CONFLICT OF INTEREST}

The authors declare that they have no conflict of interest.

\section{REFERENCES}

Afful, S., Anim, A. K., \& Serfor-Armah, Y., (2010). Spectrum of Organochlorine Pesticide Residues in Fish Samples from the Densu Basin. Research Journal of Environment and Earth Science, 2(3), 133-138.

Alcock, R. E., Behnisch, P. A., Jones, K. C., \& Hagenmaier, H., (1998). Dioxin-like PCBs in the environment-human exposure and the significance of sources. Chemosphere, 37, 1457-1472.

Berijani, S., Assadi, Y., Anbia, M., Milani Hosseini, M. R., \& Aghaee, E. (2006). Dispersive liquid-liquid microextraction combined with gas chromatography-flame photometric detection. Journal of Chromatography A, 1123(1), 1-9.

Darko, G., \& Akoto, O. (2008). Dietary intake of organophosphorus pesticide residues through vegetables from Kumasi, Ghana. Food and Chem. Toxicolol., 46, 3703-3706.

Davies, D. L., \& Barlow, H. L. (1995). Can environmental estrogens cause breast cancer? Sci. Am., Pp. 144-147.

Ezemonye, L., Ogbeide, O., \& Tongo, I. (2015). Distribution and ecological risk assessment of pesticide residues in surface water, sediment and fish from Ogbesse River, Edo state Nigeria. Journal of Environmental Chemistry and Etoxicology, 7(2), 20-30.

Furst, P., Furst, C., \& Groebel, W., (1990). Levels of PCDDs and PCDFs in food-stuffs from the Federal Republic of Germany. Chemosphere, 20, 787-792.
Giampiero, P., Teresa, G., Elisa, Z., \& Patrizia, S. (2005). Residue analysis of organophosphorus pesticides in animal matrices by dual column capillary gas chromatography with nitrogen-phosphorus detection. Journal of Chromatography $A$, 1071(1-2), 67-70.

Gonçalves, C., \& Alpendurada, M. F. (2002). Multiresidue method for the simultaneous determination of four groups of pesticides in ground and drinking waters, using solid-phase microextraction-gas chromatography with electron-capture and thermionic specific detection. Journal of Chromatography A, 968(1-2), 177-190.

Hung, H., Halsall, C. J., Blanchard, P., Li, H. H., Fellin, P., \& Stern, G. (2002). Temporal trends of organochlorine pesticides in the Canadian Arctic Atmosphere. Environ. Sci. Technol., 36, 862-868.

Joseph, A., Mohammed, Z., Jafiya, L., Ogugbuaja, V. O. (2013). Organochlorine Pesticide Residues in Fish Samples from Alau Dam, Borno State, North Eastern Nigeria. J. Environ. Anal. Toxicol., 3, 171.

Joseph, C. A., Zakari, M., Lami, J., \& Stephen, I. A. (2013). Organophosphorus Pesticide Residues in Different Tissues of Fish Samples from Alau Dam, Borno State, Nigeria. World Journal of Fish and Marine Science, 5(5), 519-526.

Metcaff, R. L. (1997). Pesticides in aquatic environment. In: Khan, M.A.Q., P. 127. (Ed) Pesticides in Environment. Plenum Press, New York.

Shokrzadeh, M., Saeedi, S. S., Saravi, Y., \& Zehtab, Y. (2009). Lindane Residues in Cultivated Cucumber and in the Most Consumed Fish in Caspian Sea (Iran), II Toxicology and Industrial Health, 25(8), 517-523.

Ogah, E., Ushie, A. O., Nkom, P. Y., Amah, S. O., Ugwuja, D. I., \& Abiaziem, C. V. (2016). Determination of organochlorine pesticides in river Benue at Agatu using gas-chromatograph equipped with electron capture detector. Ewemen Journal of Analytical \& Environmental Chemistry, 2(1), 45-50.

William, J., Tagoe, L., Drechsel, P., Kelderman, P., Gijzen, H., \& Nyarko, E. (2008). Accumulation of persistence organochlorine contaminants in milk and serum of farmers from Ghana. Environmental research, 106(1), 17-26. 